\title{
Recall it again, Sam. Practices of Repetition in the Security Council
}

\author{
Wouter Werner ${ }^{1}$ \\ Professor of international law, Centre for the Politics of Transnational Law, \\ Vrije Universiteit, Amsterdam, The Netherlands \\ w.g.werner@vu.nl
}

\begin{abstract}
Security Council resolutions seldom only appear only once. More often than not, they are recalled, reiterated, recognised, re-emphasised or reaffirmed in subsequent resolutions. In this article, I study some of the effects of such acts of repetition. Based on an analysis of acts of repetition in films and novels, I argue that acts of repetition are related to (a) the problem of origins, (b) the problem of authorship/authority and (c) the problem of continuity and change. Through acts of repetition, resolutions can claim that they had already begun before they were enacted, that there was something "before the beginning". Moreover, acts of repetition help securing the continuity of the author (authority) of resolutions. Finally, acts of repetition make it possible to confirm and at the same time adapt earlier statements or rules of law.
\end{abstract}

\section{Keywords}

repetition - Security Council resolutions - beginnings - authorship - preambles subjectivity

1 I would like to thank Philip Liste for bringing the topic of repetition to my attention and for urging me to take it more seriously than I had done before. Thanks also to Mark Drumbl and Martti Koskenniemi for encouraging me to pursue the study of repetition in Security Council practices. I also would like to thank the participants of two successive workshops in Amsterdam (Vrije Universiteit) and Lund as well as Ulf Linderfalk for their useful comments.

(C) WOUTER WERNER, 2017 | DOI 10.1163/15718107-08602001

This is an open access article distributed under the terms of the prevailing CC-BY-NC license at the time of publication. 
The sun shone, having no alternative, on the nothing new.

SAMUEL BECKETT, MURPHY, 1

$\mathbf{1}$

\section{Introduction}

Let me start this article with an act of repetition. In 2005, the Sudanese government and the Sudan People's Liberation Movement (Army) signed a Comprehensive Peace Agreement, covering a series of previous agreements and protocols on issues of security, wealth and power sharing, governance and the southern referendum on independence. The Preamble to the Comprehensive Peace Agreement stated, inter alia, the following:

Recording and Reconfirming that in the pursuance of this commitment the Parties duly reached agreement on the following texts: The Machakos Protocol, dated 2oth July 2002, ... the Agreement on Security Arrangements, dated $25^{\text {th }}$ September $2003, \ldots$, the Agreement on Wealth Sharing, dated 7 th January 2004, ... the Protocol on Power Sharing, dated 26th May $2004, \ldots$.

Recognizing that the Parties have concluded an Agreement on a Permanent Cease Fire and Security Arrangements Implementation Modalities During the Pre-Interim and Interim Periods, dated 31st December 2004 $(\ldots)^{2}$

There is nothing exceptional about the extensive recalling of previous documents and events in the Sudan Comprehensive Peace Agreement. International law is filled with statements that are restated, calls that are recalled, things we know that are recognised and undeniable facts that are confirmed, reconfirmed or reiterated. The Comprehensive Peace Agreement itself, for example, reappears in Security Council resolutions on the peace process in

2 The Comprehensive Peace Agreement Between the Government of the Republic of Sudan and the Sudan People's Liberation Movement/Sudan People's Liberation Army, 9 January 2005, online at $\langle$ www.peacemaker.un.org/node/1369 $\rangle$, visited on 28 October 2016. 
Sudan. Security Council Resolution 1590 (2005) welcomed the Comprehensive Peace Agreement and recalled some of the obligations contained therein. Resolution 1590, in its turn, figured in subsequent resolutions such as Resolution 1591 (2005) or 1714 (2006). The latter Resolutions themselves were yet again recalled and repeated in resolutions in the years to follow (e.g. Resolutions 1779 (2007), 1769 (2007) and 1755 (2007)).

Given the centrality of repetition to (human) life, it is hardly a surprise to find practices of repetition in international law. Ecological systems and biological processes are based on repetitive patterns, as is human culture in its different manifestations. Without repetition, it would be impossible to have rituals, religion, natural sciences, language, music or law. The topic of 'repetition' has been studied extensively in disciplines such as philosophy, linguistics, literary studies, musicology, anthropology or psychology. ${ }^{3}$ Lawyers too have studied repetitive patterns in-depth, e.g. in the determination of customary law ('consistent practice') or the use of precedents by courts. ${ }^{4}$ In addition, practices of repetition can be found in numerous treaties ${ }^{5}$ and in documents produced by international organisations and their member states across

3 See for example E. Margulis, On Repeat: How Music Plays the Mind (Oxford University Press, Oxford 2013); R. Rappaport, Religion and Ritual in the Making of Humanity (Cambridge University Press, Cambridge, 1999); K.A. DeName, Repetition Compulsion: Why Do We Repeat thePast?,onlineat $<$ www.psychcentral.com/blog/archives/2013/o6/29/repetition-compulsion -why-do-we-repeat-the-past/>, visited on 12 November 2016; B. Kawin, Telling it Again and Again: Repetition in Literature and Film (Dalkey Archive Press, McLean, IL, 2015 (reprint)); S. Gendron, Repetition, Difference and Knowledge in the Work of Samuel Beckett, Jacques Derrida and Gilles Deleuze (Peter Lang, New York, 2008); S. Kierkegaard, Fear and Trembling and Repetition (Princeton University Press, Princeton, 1983 (original work from 1843)).

4 For a more theoretically grounded analysis of repetition in international law see K. Freistein and P. Liste, 'Organisation-im-Kommen: Intertextualer Institutonalismus in der Analyse von Weltorganisation', in M. Koch (ed.), Weltorganisationen (Springer, Wiesbaden, 2012) pp. 71-10o. Freistein and Liste use the term 'Praktik der Gerinnung' and, invoking Berger and Luckmann's classical study, label the products of reproduction as 'geronnenes Wissen'. P. Berger and T. Luckmann, The Social Construction of Reality: A Treatise in the Sociology of Knowledge (Penguin Books, New York, 1967). In legal theory the topic of repetition has been discussed by Andreas Philippopoulos-Mihalopoulos, 'Repetition, or the Awnings of Justice', in O. Ben-Dor (ed.), Law and Art: Justice, Ethics and Aestetics (Routledge-Cavendish, Abingdon, 2011) pp. 45-59. Just like the Phillipopoulos-Mihalopoulos chapter, my article is influenced by Kierkegaard's distinction between recollection and repetition (see section 1.2).

5 To give just two random examples: The Statute of the Council of Europe starts by reaffirming the devotion of the signatories "to the spiritual and moral values which are the common heritage of their peoples" and the Inter-American Convention on Protecting the Human Rights of the Older Person starts by: "Reiterating the intention of consolidating, within the framework 
different functional fields. ${ }^{6}$ What is more, international organisations often repeat each other's documents, resolutions and declarations. ${ }^{7}$ This shows that international law is more than a system of rules and norms. It is also a set of interconnected linguistic practices filled with self-references as well as references across different fields and actors.

The aim of this article is to explore some of the effects of repetition in international decision-making and international legal argumentation. In this context, I use the term 'repetition' in a broad sense. It refers to practices where earlier sounds, utterances or forms of behaviour are literally reproduced, as for example in religious rituals, speeches or music. In section 2, I will give a few examples of this form of repetition in films and novels and reflect on some of the effects of acts of repetition. However, I also use 'repetition' to refer to practices where something from the past is not literally quoted, but 'presented again', represented through acts of recalling, reiterating, reconfirmation, etc. As the examples above have indicated, this form of repetition is widespread in international law. In section 3 I will examine more closely how the Security Council has use this technique to link present events to what has happened in the past.

\section{Some Effects of Repetition}

What happens when linguistic utterances are repeated again and again? It is impossible to answer his question in any definite or general manner. Much will depend on the text and context of specific utterances and the way in which they are repeated. Repetition may, for example, lead to strong emotional attachment by the audience, as in Martin Luther King's famous speech where "I have a dream" and "Let freedom ring" are repeated several times, thereby emphasising the message and engendering feelings of enthusiasm and

of democratic institutions, a system of individual liberty and social justice founded upon respect for the fundamental rights of persons".

6 Again, to give just two random examples: The ministers of the state parties to wTo adopted a 'Decision on Measures for Least Developed Countries', which begins with "Reaffirming their commitment to implement fully the provisions concerning the least-developed countries contained in paras. $2(d), 6$ and 8 of the Decision of 28 November $1979(. .$.$) ") and the first sen-$ tence of the "Decision on the Outcome of the Retreat of the Assembly of the African Union", "REAFFIRMS its determination to ensure that the African Union (AU) is financed in a predictable, sustainable, equitable and accountable manner with the full ownership by its Member States"; (Assembly/Au/Dec.6o5 (XXviI).

7 Freistein and Liste, supra note 4. 
commitment. ${ }^{8}$ However, in other contexts or uttered by a less gifted speaker, the same sequence of repetitions may lead to boredom or become preposterous. Having said that, it is possible to identify some recurring issues and problems related to acts of repetition. In this section, I will set out three of these issues based on a study of repetition in film and novels: (a) repetition and beginnings, (b) repetition and authorship, and (c) repetition and time. In section 2.1 I take the first two topics together, followed by a discussion of repetition and time in section 2.2 .

\subsection{Repetition, Authorship and Beginning}

Questions of repetition are often linked to questions of origins and beginnings. Take for example Woody Allen's Manhattan (1979), which starts with the following monologue:

Chapter One. "He adored New York City. He idolized it all out of proportion". Uh, no, make that: "He-he ... romanticized it all out of proportion. ... Ahhh, now let me start this over. "Chapter One. He was too romantic about Manhattan as he was about everything else. ... Nah, no

... corny, too corny ... "Chapter One. He adored New York City. To him, it was a metaphor for the decay of contemporary culture. No, it's gonna be too preachy. ... Chapter One. He adored New York City, although to him, it was a metaphor for the decay of contemporary culture. ...Too angry. I don't wanna be angry. Chapter One. He was as ... tough and romantic as the city he loved. Behind his black-rimmed glasses was the coiled sexual power of a jungle cat". I love this. "New York was his town. And it always would be". 9

By beginning over and over again, the film has started by repeatedly suspending its own beginning. ${ }^{10}$ The constant repetitions of the opening introduce the

8 Speech of 28 August 1963 . Available online at American Rhetoric $<$ www.americanrhetoric .com/speeches/mlkihaveadream.htm $>$, visited on 12 November 2016.

9 W. Allen (1979), Manhattan, p. 1 ('chapter one'). Transcript available online at $<w w w$ .script-o-rama.com/movie_scripts/m/manhattan-script-transcript-woody-allen.html>, visited on 12 November 2016.

10 Note that this theme inverts the beginning of Woody Allen's 1975 comedy play God, where a playwriter in Athens 500 B.C. struggles to find a closing scene: "Actor: Nothing, just nothing; Writer: What?; Actor: Meaningless. It's Empty; Actor: Of course. What are we discussing? We're discussing the ending; Writer: We are always discussing the ending; Actor: Because it's hopeless; Writer: I admit it's unsatisfying; Actor: Unsatisfying? It's not even believable. The trick is to start at the ending when you write a play. Get a good strong 
viewer to a number of core topics of the film as a whole. We get glimpses of the main character and learn about a leitmotif of the film: the filmmaker's ambivalent yet intense love for New York. The act of repetition thereby creates a narrative structure: the first 'chapter one' gets linked to the second 'chapter one', which is linked to the third, etc. However, the opening of Manhattan is not just a playful introduction to the rest of the film itself. It also hints at foundational problems that have plagued Western philosophy for centuries: is it possible to ground knowledge on a beginning, on some form of 'original'? As Sarah Gendron has argued, if it is not possible to identify some sort of definite beginning,

if in other words, every beginning had already happened, if every beginning is just beginning again, (...) how can one differentiate definitely between one thing or another without reference to where each object begins? What becomes of authenticity and authority ...? What if the original is no more original than the copy?11

In many literary works as well, practices of repetition are linked to either the beginning or to reflections on the beginning of a text. Take for example Samuel Beckett's Molloy (1951). The novel starts with Molloy's inner musings in the room of his deceased mother. Molloy seems to have lost most of his memories, hardly manages to locate himself in the present and constantly hints at his upcoming death. Apparently, he makes money by writing 'pages' for an unnamed man, even though Molloy claims he is unable to work, has forgotten how to spell and lost "half of the words". After more than one and a half page, the novel quite abruptly takes up the issue of beginnings. Molloy reports how the unnamed man has criticised his writings because of their faulted beginnings. Molloy accepts the critique, acknowledging that he mistakenly "began at the beginning", and starts over again by a series of repetitions:

He told me I'd begun all wrong, that I should have begun differently. He must be right. I began at the beginning, like an old ballocks, can you imagine that? Here's my beginning. Because they're keeping it apparently. I took a lot of trouble with it. Here it is. It gave me a lot of trouble. It was the beginning, do you understand? Whereas now it's nearly the end. Is what I now know any better? I don't know. That's beside the point. Here's

ending and then write backwards; Writer: I've tried that. I got a play with no beginning; Actor: That's absurd". W. Allen, God, A Comedy in One Act (French, New York, 1975).

11 Gendron, supra note 3, p. xiii. 
my beginning. It must mean something, or they wouldn't keep it. Here is it. ${ }^{12}$

Both in Manhattan and in Molloy the acts of repetition turn the initial beginning of the story into the first beginning. The second beginnings are of course similar to the first beginnings - otherwise we would not recognise them as such. Yet, they do more than just copy the earlier beginning: only because there is a second beginning, do we recognise the other one as the first. In that sense, repetition emphasises similarity and difference at the same time. It reproduces something that already exists, but at the same time transforms that which already exists into something new. In this context, Descombes has argued that a 'first' or 'original' event can be compared to a dress rehearsal in theatre. The point of a dress rehearsal is to repeat that which is to come (the premiere), and only because of the premiere is it possible to have a dress rehearsal: "The origin must therefore be conceived as a dress rehearsal (...) in the theatrical sense of these words: the reproduction of the first performance, yet prior to this performance". ${ }^{13}$

\subsection{Repetition and Subjectivity}

The examples of Manhattan and Molloy illustrate what Søren Kierkegaard has called the 'impossibility of repetition', that is: the impossibility of repetition without transformation. ${ }^{14}$ As Kierkegaard points out: "The dialectics of repetition is easy, for that which is repeated has been - otherwise it could not be repeated - but the fact it has been makes repetition into something new". 15 In other words: bringing the past into the present does not leave the repeated object, person or event untouched; it endows it with a new, actualised meaning. However, there is more at stake than only the impossibility of copy-pasting the past into the present. Repetition also has to do with the way in which the repeating subject relates to that which is repeated. ${ }^{16} \mathrm{~A}$ good example can be

\footnotetext{
12 S. Beckett (1955), Molloy (Olympia Press, Paris) p. 8.

13 V. Descombes, Modern French Philosophy (Cambridge University Press, Cambridge, 1980) p. 145; as quoted by Gendron, supra note 3, p. 20.

14 S. Kierkegaard, Fear and Trembling and Repetition (Princeton University Press, Princeton, 1983 (original work from 1843)).

15 Ibid., p. 146.

16 This links to a more fundamental point in Kierkegaard's philosophy, the need to put oneself at stake, also in acts of repetition. This point transcends the aims and boundaries of this article and will therefore be left undiscussed here. For a discussion see, inter alia, I.A. Barliba, 'Søren Kierkegaard's Repetition. Existence in Motion', 1,1 Symposion (2014) pp. 23-49. DoI: 10.5840/symposion2014113; A.J. Burges, 'Repetition- A Story of Suffering', in
} 
found in Jorge Borges' The Aleph. ${ }^{17}$ The novel starts with the narrator noticing that a new advertisement is placed on a billboard, on the "burning February morning" that his beloved Beatriz Viterbo died. The narrator is deeply hurt by this in and of itself innocent event because it indicates "that the wide and ceaseless universe was already slipping away from her and that this slight change was the first of an endless series".18 In other words, the narrator realises that time will do its unavoidable job of change: Beatriz alive is different from Beatriz dead, and even his own memory of Beatriz will unavoidably transform over time. However, the narrator refuses to accept the workings of time and resists: "the universe may change, but not me". ${ }^{19} \mathrm{He}$ chooses to fight the effects of time through repetition in order to preserve the past as it is. He seizes the opportunity to visit Beatriz' family home and turns this into an annually repeated and strictly routinized visit; he emphasises that his visits consist of 'waiting once again', studying Beatriz' picture and photo's 'once again', 'recalls' her birthday and provides the reader with a long sentence in which Beatriz' name is repeated over and over again: "Beatriz Viterbo in profile and in full colour; Beatriz wearing a mask, during the Carnival of 1921; Beatriz at her First Communion; Beatriz on the day of her wedding to Roberto Alessandri; Beatriz soon after her divorce, at a luncheon at the Turf Club; Beatriz at a seaside resort in Quilmes with Delia San Marco Porcel and Carlos Argentino; Beatriz with the Pekingese lapdog given her by Villegas Haedo; Beatriz, front and three-quarter views, smiling, hand on her chin... ${ }^{20}$ However, as may be expected, the attempt to fight time is doomed to fail. The narrator decides that from now on he will devote his life to remembering Beatriz, but this decision is corrupted right from the start. The narrator wants to remember Beatriz in an idealised way, leaving out her annoyance at his earlier devotion, his previous hope at success and his feelings of humiliation when she did not appreciate his behaviour:

R.L. Perkins (ed.), International Kierkegaard Commentary: Fear and Trembling and Repetition Vol. 6 (Mercer University Press, Macon, GA, 1993) pp. 247-262; E. Mooney, 'Repetition: Getting the World Back', in A. Hannay and G. Marino (eds.), The Cambridge Companion to Kierkegaard, (Cambridge University Press, Cambridge, 1998) pp. 282-307; T.W. Dickinson, 'Repeating, Not Simply Recollecting: Repetition: On Kierkegaard's Ethical Exercises', 50:4 Sofia (2011) p. 657. DOI: 10.1007/s11841-011-0259-z.

17 J.L. Borges, The Aleph (Penguin Classics, New York, 2004 (originally published in 1949)). My discussion of The Aleph builds on the essay published on Yago, Hopelessness and Potency: Borges' "El Aleph", <www-personal.umich.edu/ scolas/Words/Essays/hopelessness _and_potency.htm>, visited on 4 November 2016.

18 Ibid., p. 1.

19 Ibid.

20 Ibid. 
"I knew that at times my fruitless devotion had annoyed her; now that she was dead, I could devote myself to her memory, without hope but also without humiliation". 21

Borges' story nicely captures the interplay between repetition, transformation and subjectivity. After all, the point of repeating Beatriz over and over again is to stabilise the identity of the narrator in the face of events that escape him ("the universe may change, but not me"). However, the attempt to fight the workings of time through repetition fails because the latter is more than bringing an untouched past into the present. Repetition involves an act of creation, of presenting anew that which lies in the past. This implies that repetition requires the active involvement of the repeating subject. She is not a passive, neutral transmitter of a completed past into a blank present. Instead, repeating is an act of re-appropriation, of retaking the past as one's own, in relation to the present and future. ${ }^{22}$ What is more, the repeating subject makes a claim that it is appropriate to repeat a particular aspect of the past at a particular moment in the present. The narrator of The Aleph not only fails to preserve the past or to protect his own identity against the workings of time. He also fails in terms of appropriate behaviour: his way of repeating Beatriz comes across as obsessive and narcissistic, with little respect for the integrity of his beloved one. Ironically, his attempts to fight change have transformed him into someone who seeks to possess the memory of his beloved one.

\footnotetext{
$21 \quad$ Ibid.

22 Online Etymology Dictionary, <www.etymonline.com/index.php?term=appropriate $>$, visited on 8 November 2016. For Kierkegaard the notion of repetition as a form of retaking the past is crucial, as it shows how individuals have put themselves at stake in acts of repetition. This is nicely illustrated by the story of Constantin Constantinus, the narrator of the first part of Kiergekaard's Repetition. At some point in the story Constantinus decides to test his out his reflections on the importance of repetition by redoing a trip to Berlin. His earlier visit to the German capital had been very pleasurable and Constantinus makes an attempt to relive this experience by visiting the exact same places and by undertaking the exact same activities. However, he is soon to find out that the second trip is quite unlike the first, with a hotel room that is slightly different, a landlord that got married, a much less pleasurable café, an actor that disappoints when he watches him again, etc. Eventually, Constantinus gets fed up with the experiment and comes to the 'insignificant yet curious' conclusion that repetition is impossible. However, this outcome only shows that repetition is impossible if it is done backwards, as a form of recollection that leaves the subjectivity of the repeating person untouched. For Constantinus, the trip to Berlin is meant to test out a hypothesis, not to re-appropriate a past, not to link the previous trip to his own position in the present and future. For a more elaborate discussion see Barliba, supra note 16 .
} 
As was set out in the previous section, acts of repetition are linked to at least three interrelated issues: (a) beginnings, (b) authorship and subjectivity and (c) time. In this section, I will discuss each of these aspects in relation to practices of repetition by the United Nations Security Council.

\subsection{Repetitions and Preambles}

As the examples of Manhattan and Molloy show, there is a close relation between beginnings and repetitions. Both works did so in an explicit way, by problematizing their own beginnings over and over again. One would be hard pressed to find similar problematizations in international law. After all, the point of legal documents is generally way more practical than tackling philosophical or existential problems. What is more, institutions such as the Security Council cannot afford to spur existential doubts about their origins or authority. Whereas authors such as Borges or Beckett can lucidly call into question the basis of their own authorship, the Security Council needs to protect the legitimacy thereof, to shield its capacity to take binding decisions. However, this does not mean that repetition is unimportant to the Security Council. On the contrary: precisely because of its capacity to manage stability and change, the technique of repetition is omnipresent in Security Council resolutions. Just like the narrator in Aleph, the Security Council is constantly faced with a world beyond its power, a universe of change that escapes it regulatory capacities. ${ }^{23}$ And just like Borges' narrator, the Security Council seeks to domesticate these changes through repetition, thereby presenting past decisions as well as its own authorship constantly anew.

Given the close relation between repetition and beginnings, it is not surprising that most repetitions occur in preambles of legal documents, including resolutions of the Security Council. Just like prefaces to novels, preambles are "before the beginning" of a text, meant to "allow manipulation of both the speaker/author's ethos or persona as well as of the audience's reception of the text". ${ }^{24}$ The term 'preamble' is derived from the Latin pre-ambulus, to 'walk-before', which also suggests that preambles are somehow a step ahead

23 For this also see Y. Otama, Unconditional Life, The Postwar International Law Settlement (Oxford University Press, Oxford, 2016).

24 M. Edelstein, 'Before the Beginning; Nabakov and the Rhetoric of Preface', in B. Richardson (ed.), Narrative Beginnings; Theories and Practices (University of Nebraska Press, Lincoln, 2008) p. 29. 
of the rest of the text. ${ }^{25}$ And indeed nowadays preambles are mostly defined as preliminary statements accompanying legal texts and specifying their purpose or reason for enactment. The United Nations Security Council website, for example, characterises preambles to resolutions as presenting "the considerations on the basis of which action is taken, an opinion expressed or a directive given". ${ }^{26}$ In this sense, preambles match Said's famous characterisation of beginnings as the "first step in the production of meaning". ${ }^{27}$ However, the question remains whether it is indeed possible to speak of a 'first step' in the production of meaning. Every beginning of a narrative presupposes pre-existing facts and already existing structures of meaning. As a result, beginnings are necessarily rooted in paradox. As Hillis Miller has put it: "The paradox of beginning is that one must have something solidly present and preexistent, some generative source or authority, on which the development of a new story may be based". ${ }^{28}$

Repetition, as we saw before, deals with exactly this problem. Acts such as repeating or recalling offer the opportunity to begin a story by suggesting it has already begun. The possibility to hark back to what was before the beginning of a story is of particular significance for the field of law. Legal rules are assumed to be part of a bigger legal system or order, not codifications of random acts of will by those in power. The 'legal ethos', to use Shklar's terminology, "relies on what appears to have been established and accepted". ${ }^{29}$ The idea that law builds on what went before figures prominently in the 2006 report of the International Law Commission on the fragmentation of international law. After an analysis of the increasing functional specialisation of international law, the report turns to the concept of international law. At several places it stresses that international law is a systemic whole and that "the various decisions, rules and principles of which the law consists do not appear randomly

25 See the Online Etymology Dictionary, <www.etymonline.com/index.php?term=preamble>, visited on 27 October 2016.

26 United Nations Security Council website, <www.un.org/en/sc/documents/resolutions/>, visited on 27 October 2016. See also the definition in the free legal dictionary online, $<$ www.legal-dictionary.thefreedictionary.com/preamble>, visited on 27 October 2016.

27 E. Said, Beginnings: Intention and Method (Basic Books, New York, 1975) p. 5 .

28 H. Miller, Reading Narrative (University of Oklahoma Press, Norman, 1999) p. 57. For a similar argument see A. Oz, The Story Begins: Essays on Literature (Harcourt Brace, New York, 1998) pp. 8-9: "Isn't there always, without exception, a latent beginning-before-the -beginning? A foreword to the introduction to the prologue?"

29 J. Shklar, Legalism; Law, Morals, and Political Trials (Harvard University Press, Cambridge, MA, 1986 (first edition published in 1964)) p. 10. 
related to each other". ${ }^{30}$ At the same time, the report calls upon the professional international lawyer to realise the coherence and systemic character of international law. If new or unexpected phenomena occur, "it is the task of reasoning to make the unfamiliar familiar by integrating it into received patterns of thought or by amending those patterns so that the new phenomenon can be accommodated". ${ }^{31}$ In more general fashion, the report argues that those who apply the law have a "political obligation to make their decisions cohere with the preferences and expectations of the community whose law they administer". ${ }^{32}$

Of course, the Security Council can neither be equated with a professional lawyer nor with bodies that apply existing law. Nevertheless, also for a body with the power to deal with exceptional circumstances, it is important to create a sense of narrative coherence, to show how current decisions relate to previous acts and how they fit in broader and already existing patterns of law. By recalling previous resolutions as well as existing normative frameworks, decisions by the Security Council are presented as more than random decisions that regulate isolated affairs; they become part of a bigger history of international regulation. Thus, when the Security Council recently adopted a resolution on Haiti in October 2016, it created a sense of narrative coherence by first 'reaffirming' no less than 17 preceding resolutions from the past 12 years, suggesting that in some way the resolution had already begun well before it was enacted. ${ }^{33}$

In addition, acts of recalling and repeating suggest an authorship that supposedly lies before the beginning. In preambles, authorship is often explicitly claimed, sometimes by the institution or group issuing the document (e.g. "The Security Council"; "The Parties"), sometimes by an idealised entity (e.g. "We The Peoples..."). In this way, treaties and resolutions introduce an author that has 'produced' the text that follows and that thus must be assumed to precede it. It could also be the case that different authors are combined through acts of related repetitions. Take for example Security Council Resolution 1267 (15 October 1999), on the situation in Afghanistan and the fight against international terrorism. Since its adoption Resolution 1267 has been

30 ILC Study Group on the Fragmentation of International Law finalized by M. Koskenniemi, Fragmentation of International Law: Difficulties Arising from the Diversification and Expansion of International Law (UN Doc A/CN.4/L.682), p. 23.

31 Ibid., pp. 16-17.

32 Ibid., p. 24.

33 SC Res 2313 (17 October 2016). 
repeated at least 18 times. ${ }^{34}$ The Resolution itself starts by reaffirming previous resolutions of the Security Council, including Resolution 1189 (13 August 1998). The latter Resolution informs the reader that the Security Council is "mindful of General Assembly resolution 52/164 of 15 December 1997 on the International Convention for the Suppression of Terrorist Bombings". In this way, the Security Council links both the content and the authorship of Resolution 1189 to what happened before in the General Assembly. Resolution 52/164, in its turn, begins by 'recalling' one of the General Assembly's previous resolutions, 49/6o of 9 December 1994, a resolution that once again recalls an earlier resolution, namely 3034 (18 December 1972). Resolution 3034 recalls a quite familiar resolution: The Friendly Relations Declaration of 1970 (Resolution 2625). In the Friendly Relations Declaration, there is yet another recalling of a previous resolution, 1815 (18 December 1962). The latter Resolution refers to the United Nations Charter itself, which as we have seen, was written by a fictitious group of authors that allegedly precede the text, "We, the Peoples".

Another example of cross-referencing between different authors can be found in Resolution 2161 (2014). The Resolution starts off by recalling some previous resolutions, including the 'usual suspects' when it comes to counterterrorism, Resolution 1267 (2001) and 1373 (2001). However, Resolution 2161 does more than recalling both Resolutions in a general way. It also specifies more concretely what some of the abstract norms contained in both Resolutions mean. In this context, Resolution 2161 'recalls' the recommendations formulated by the Financial Action Task Force (FATF), an inter-governmental body, which according to its own website "works to generate the necessary political will to bring about national legislative and regulatory reforms in these areas". ${ }^{35}$ The FATF recommendations are not binding, but aim to bring about national legislation, inter alia in the field of terrorist financing. The more concrete meaning of Resolution 1373 was thus set out in a non-binding recommendation of an intergovernmental body, whose recommendations were subsequently recalled

34 See the following Security Council Resolutions: 1455 (2003); 1526 (2004); 1617 (2005); 1624 (2005); 1735 (2006); 1822 (2008); 1904 (2009); 1988 (2011); 1989 (2011); 2082 (2012); 2083 (2012); 2160 (2014); 2161 (2014); 2170 (2014); 2199 (2015); 2249 (2015); 2253 (2015); 2255 (2015).

35 See <www.fatf-gafi.org/about/>, visited on 12 November 2016. The text of Resolution 2161 reads as follows: "Recognizing the need for Member States to prevent the abuse of non governmental, non-profit and charitable organizations by and for terrorists, and calling upon non-governmental, non-profit, and charitable organizations to prevent and oppose, as appropriate, attempts by terrorists to abuse their status, while recalling the importance of fully respecting the rights to freedom of expression and association of individuals in civil society and freedom of religion or belief, and noting the relevant recommendation and guidance documents of the Financial Action Task Force". 
in the preamble to yet another chapter viI resolution, 2161. In this way, acts of repetition add to what Freistein and Liste have called 'inter-textual institutionalism'. This term refers to the practice of cross-references to and restatements of texts that can be found in international organisations and institutions. Through this practice of repeating or restating each other's texts, institutions or organisations confirm each other's legitimacy and 'thicken' the meaning and authority of their linguistic products. ${ }^{36}$

\subsection{Repetition, Similarity and Difference}

Acts of repetition create similarity and difference at the same time. Repetition is only possible if there is a similarity between the present and the past, if that which is done now somehow resembles what has happened in the past. In this way, the present is represented as a recurrence of the past. At the same time, repetition also presumes that the present can be differentiated from the past, that the past is re-appropriated and updated in light of what goes on in the present. In this way, the past is presented anew, is re-presented and thereby unavoidably (slightly) changed. Both aspects of repetition recur in preambles of Security Council resolutions.

In some resolutions, the present is read as yet another instance of something we know already. On the same day as the second 2003 terrorist attacks in Istanbul, for example, the Security Council adopted Resolution 1516 (20 November 2003). The Resolution reaffirms Resolution 1373 (28 September 2001), which in its turn reaffirms Resolution 1368, which was adopted a day after $9 / 11$. In this way, the attacks in Istanbul are linked to the 2001 attacks on the United States, as well as to the concerns, plans for action and recollections of already existing norms that are contained therein. The same happened after the 2004 Madrid train bombings and the London attacks of 2005. In both cases, the Security Council responded within hours, adopting Resolution 1530 (2004) and 1611 (2005), containing similar references to Resolution 1373 as the Istanbul Resolution. In other words: before Al Qaida involvement could be definitely confirmed, the Security Council had already placed the Istanbul, Madrid and London attacks in the narrative of $9 / 11$ and the international fight against global terrorism. This narrative was later deliberately extended to include other groups such as Daesh (ISIL) in Resolution 2249 (2015), adopted directly after the attacks in Paris. Already a year before Resolution 2249, the Security Council had linked Al Qaida, the Al Nusrah Front and Daesh in Resolution 2170 (2014), which recalls Resolution 1373, followed by reaffirmations of the UN Charter, and the threats posed by international terrorism.

$36 \quad$ Freistein and Liste, supra note 4, pp. 71-100. 
Conversely, events in the present can also be placed in a certain perspective because things from the past are not repeated. A good example is Resolution 1441 (2002), on Iraq's non-compliance with earlier Security Council resolutions. The Resolution turned into probably the key document for assessing the legality of the 2003 invasion by the us-led coalition, not only at the time but also in governmental expert reports that were issued years after the war. ${ }^{37}$ The Resolution contains an attempt to keep the permanent members of the Security Council on board by repeating what they could agree on: the content of some ten earlier resolutions as well as the determination that Iraq had failed to comply with them so far. In this context, it is also noteworthy what is excluded from Resolution 1441. One of the main justifications to use force against Iraq offered by the United States prior to the 2003 invasion was that Saddam Hussein's regime had close ties to Al Qaida. To be sure, the claim was unfounded, but this did not prevent the Us administration at the time from repeating it over and over again. As, inter alia, Vice President Cheney argued several times, "(Saddam's) regime has had high-level contacts with Al Qaeda going back a decade and has provided training to $\mathrm{Al}$ Qaeda terrorists"38 and at the same time "aids and protects terrorists, including members of Al Qaeda". ${ }^{39}$ However, none of the recalled resolutions in Resolution 1441 deals with international terrorism. Had the Security Council preferred to frame the problem of Iraq in terms of international terrorism, it could have chosen from a wide range of previous resolutions, including the often-quoted ones such as 1269 or 1373 . It could then, to use Spreber and Wilson's terminology, have made an attempt to frame the "cognitive environment" of its audiences in a particular way. ${ }^{40}$ The story told in the preamble of Resolution 1441, however, is a very different one.

37 In the Netherlands, for example, the political support for the Iraq war given by the Dutch government was critically examined in the Davids report. The report extensively discusses the meaning and scope of Resolution 1441. The report is available (in Dutch) at $<w w w$ .rijksoverheid.nl/documenten/rapporten/2010/o1/12/rapport-commissie-davids $>$, visited on 12 November 2016. In the UK the Iraq war was scrutinised in the Chilchot report, which also devoted much attention to the implications of Resolution 1441. Available online at $<$ www.iraqinquiry.org.uk>, visited on 12 November 2016.

38 December 2 2002, Speech of Vice President Cheney at the Air National Guard Senior Leadership Conference.

39 January 30 2003, Speech of Vice President Cheney to 3oth Political Action Conference in Arlington, Virginia.

40 See, inter alia, D. Sperber and D. Wilson, 'Précis of Relevance: Communication and Cognition', 10 Behavioural and Brain Sciences (1987) pp. 697-754. The term 'cognitive environment' is defined as "a set of facts that is manifest to an individual" (ibid., p. 699). 
It focuses exclusively on the non-compliance of Iraq with the obligations from earlier resolutions adopted in the years after the Kuwait invasion.

Acts of repetition thus convey important information about the way in which present and future issues should be understood. As we saw in the previous section, acts of repetition do not copy-paste, but re-appropriate the past, make it appropriate for present and future purposes. After all, repetition always involves a choice: what is considered to be worthy of repetition and what is not? The case of Resolution 1441 underlines the importance of this question: apparently resolutions that contextualised the problem in terms of Iraq's failure to comply were deemed relevant, and resolutions pertaining to international terrorism were not. Acts of repetition, if only because they involve selection, always add meaning to what lies in the past. As the examples discussed in the previous section show, it may be possible to (literally) reproduce a text, but it is virtually impossible to do the same with a context. Since the meaning of a text is also dependent on the context in which it is used, the act of repetition necessarily comes with changes or updates in meaning. This is why literally repeated quotes may sometimes strike us all of a sudden as deep insights, and in other cases as hilarious, tragic or totally inappropriate. In terms of speech act theory, repetitions are not only about the propositional content of the repeated material, but also about the act of repeating itself. ${ }^{41}$ By repeating something the speaker makes the (implicit) claim that it is fitting to repeat something in this particular context. Also, she generally will make the (implicit) claim that repeating previous statements means something in this particular context. Therefore, it would be a mistake to assess repetitive statements only in terms of their correct representation of the original. Often, it is much more important to pose the question why something is repeated in the first place, and how the act of repetition itself is re-appropriated in subsequent cases.

Take for example Resolution 1368 (2001), adopted by the Security Council one day after the $9 / 11$ attacks. The preamble of the Resolution recognises "the inherent of individual and collective self-defense in accordance with the Charter". This recognition of the right to self-defence itself is subsequently reaffirmed in Resolution 1373 (2001), ${ }^{42}$ a resolution that has been recalled in more than 30 resolutions since. ${ }^{43}$ At first sight, 'recognising' the inherent right to

41 For the distinction between propositional content and the illocutionary force of a speech see, inter alia, J. Searle, Speech Acts (Cambridge University Press, Cambridge, 1969).

The text contained in Res 1373 (2001) reads as follows: "Reaffirming the inherent right of individual or collective self-defence as recognized by the Charter of the United Nations as reiterated in resolution 1368 (2001)".

43 See the following Resolutions adopted by the Security Council: 1377 (2001), 1438 (2002), 1440 (2002), 1450 (2002), $145^{2}$ (2002), 1455 (2003), 1465 (2003), 1516 (2003), 1526 (2004), 
self-defence in accordance with the UN Charter is highly unspectacular. The right to self-defence is already set out in Article $5^{1}$ of the UN Charter, has been accepted as a right under customary law, has been applied by judicial bodies, discussed by scholars worldwide, etc. Therefore, the importance of repeating the right to self-defence cannot be found in the text but must be sought in the context. The question was not whether the Security Council correctly repeated a commonplace of international law, but rather what it meant to repeat this commonplace in the context of the 9/11 attacks. Linking something familiar (self-defence) to something unprecedented (the $9 / 11$ attacks) creates new possibilities of reading that which we thought to know. Of course, this does not automatically imply that the meaning of self-defence has changed for future occasions as well. Whether this is the case or not depends on how Resolution 1373 itself is re-appropriated, on the ways in which the recognition of the right to self-defence in Resolution 1368 is linked to subsequent and possible future events. As may be expected in the highly contentious field of international security, different interpretations of the impact of Resolution 1368 on the law of self-defence have been proposed. It is not the aim of this article to discuss the content or persuasiveness of these different interpretations. ${ }^{44}$ However, it is worth noticing that the 'mere' repetition of a long-established right has given rise to intense legal debates on the lawfulness of unilateral force against nonstate actors. Apparently, what we thought to know had to be re-appropriated over and over again.

1530 (2004), 1535 (2004), 1566 (2004), 1611 (2005), 1617 (2005), 1624 (2005), 1735 (2006), 1787 (2007), 1805 (2008), 1822 (2008), 1904 (2009), 1963 (2010), 1988 (2011), 1989 (2011), 2082 (2012), 2083 (2012), 2129 (2013), 2133 (2014), 2160 (2014), 2161 (2014), 2170 (2014), 2178 (2014), 2195 (2014), 2199 (2015).

44 Among the many sources on the topic see Y. Dinstein, War, Aggression and Self-Defense, Cambridge (Cambridge University Press, Cambridge, 2012); T. Franck, Recourse to Force: State Action against Threats and Armed Attacks, (Cambridge University Press, Cambridge, 2002); C. Gray, International Law and the Use of Force (Oxford University Press, Oxford, 2008). See also the separate opinion of Judge Kooijmans in the Armed Activities case, where he recalls his earlier separate opinion to the ICJ's advisory opinion on the Legal Consequences of the Construction of a Wall in the Occupied Palestinian Territory. According to Kooijmans, the old interpretation of self defense, linking it to state involvement, "no longer seems to be shared by the Security Council, since in resolutions 1368 (2001) and 1373 (2001) it recognizes the inherent right of individual or collective selfdefence without making any reference to an armed attack by a State". Opinion available at <www.icj-cij.org/docket/files/116/10463.pdf >. A. Cassese, 'Terrorism is Also Disrupting Some Crucial Legal Categories of International Law', 12 European Journal of International Law (2001) p. 996. 
Practices of repetition are crucial for the development of normative legal systems. Through repetition new rules and decisions can be framed in terms of laws that already existed before. In this way, it is possible to treat law as a relatively autonomous sub-system, where cases are decided on the basis of considerations intrinsic to the legal system. ${ }^{45}$ Moreover, through repetition legal rules can perform one of their core functions: to stabilise expectations in the face of an ever-changing world. ${ }^{46}$ Repetition makes it possible to frame new phenomena in a language that is familiar. Thus, when faced with new and unforeseen problems, international lawyers sometimes resort to 'restatements' of existing rules, as to make sure that novel issues can be understood in terms that we are familiar with. ${ }^{47}$ At the same time, repetition makes it possible to adapt or update the law. As Wittgenstein has argued, in most cases the meaning of words consists in their use in language. ${ }^{48}$ If existing terms are used in different contexts or to capture novel phenomena, their meaning is also adapted in some way or the other.

This article has focused on this dual role of repetition: as a practice that solidifies and at the same time adapts and updates the meaning of rules and decisions. This is not only something that can be witnessed in express acts of repetition. Rule application, for example, also contains an element of repetition, which both solidifies and updates the meaning of the rule in question. ${ }^{49}$ The dual role of repetition is captured the idea of repetition as a form of reappropriation. Repetition not only refers back to something in the past; the repeating person makes the repeated object it her own (again), while claiming that it is appropriate to do so. In this way, repetition connects to some core problems in legal theory and practice: (a) the problem of origins, (b) the problem of authorship and (c) the problem of continuity and change.

45 M. Weber (G. Roth and C. Wittich, (eds.)), Economy and Society: An Outline of Interpretative Sociology (University of California Press, Berkely, 1978 (original title Wirtschaft und Gesellschaft: Grundriss der Verstehende Soziology, Mohr Siebeck, 1921/1922)); For a discussion of Weber's position, see D. Trubek, 'Max Weber on Law and the Rise of Capitalism, Paper 4001 Yale Law School, Faculty Scholarship Series (1972) p. 730.

46 N. Luhmann, Law as a Social System (Oxford University Press, Oxford. 2004).

47 For an analysis of 'restatements' in international law see W. Werner, 'The Law at Hand; What Does it Mean to State the Law in a 'Manual'?', in H. Krieger, Legitimacy and LawMaking in International Humanitarian Law (2017, forthcoming).

48 L. Wittgenstein, G.E.M. Anscombe and R. Rhees (eds.), G.E.M. Anscombe (trans.), Philosophical Investigations (Blackwell, Oxford, 1953) p. 43.

49 Thanks to Ulf Linderfalk for pointing this out. 
In this article I have studied the use of repetitions in counter-terrorism resolutions adopted by the UN Security Council. For the legitimacy of the UN counter-terrorism regime, it is important that these resolutions are (perceived as) more than a series of unconnected ad hoc decisions. They should form a more or less coherent body of norms, which nevertheless is flexible enough to deal with new circumstances. Repetition is one of the techniques through which this is achieved. Repetitions generally occur in preambles to resolutions, often in the form of acts of recalling, recognising, reiterating, etc. In this way, preambles suggest that Security Council resolutions are rooted in pre-existing origins and written by pre-existing authors (authorities). At the same time, they make it possible to frame novel events in terms of what went before. Terrorist attacks such as the ones in Istanbul, London, Madrid or Paris, for instance, are presented as part of a bigger chain of attacks since 9/11. Finally, acts of repetition have put new light on past norms and decisions, as was shown by the post $9 / 11$ recalling of the right to self-defence. The practice of repetition in the Security Council illustrates the idea of repetition as 're-appropriation', a form of recalling the past that opens up new ways of thinking about the present, the future as well as the person who presents anew what went before. 